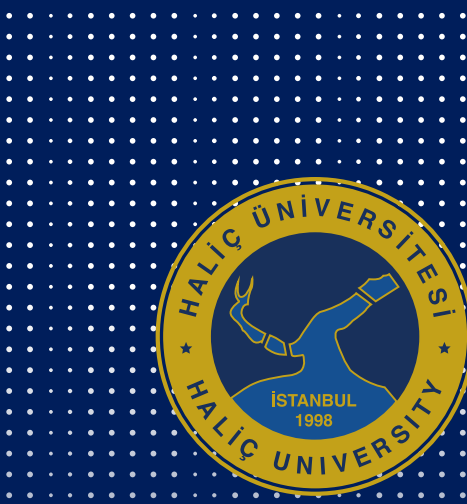

\title{
RESEARCH
}

\section{THE RELIABILITY OF HANDMADE MASK VIDEOS PRESENTED ON YOUTUBE® PLATFORM IN COVID-19 PANDEMIC}

\begin{abstract}
In this study, we aimed to determine whether these instructive videos on handmade masks published on YouTube ${ }^{\circledR}$ are compatible with the criteria issued by Centers for Disease Control and Prevention (CDC) and World Health Organization (WHO). The present study investigated 184 videos yielded by a search on YouTube ${ }^{\circledR}$ with the keywords "DIY mask, handmade mask, fabric mask" during the period from January 01, 2020 to April 01, 2020. The videos were categorized according to the criteria recommended by WHO and CDC. Audience interest parameters such as total members, views, likes, dislikes, comments made, video sources and upload date were evaluated. $66.8 \%(\mathrm{n}=123)$ of the instructive YouTube ${ }^{\circledR}$ videos concerning handmade masks were uploaded by craft-DIY-tutorial pages, 57.1\% $(\mathrm{n}=105)$ included the sewing method, 97.3\% $(\mathrm{n}=179)$ included unsuitable material usage as per $\mathrm{CDC}, 98.4 \%(\mathrm{n}=181)$ were not compatible with CDC directives, 99.5\% ( $\mathrm{n}=183$ ) used non-fluid-resistant material, 78.3\% $(\mathrm{n}=144)$ involved masks that collapse against the mouth and $95.7 \%(\mathrm{n}=176)$ involved gaps between the face and the mask. We found that the videos published on YouTube ${ }^{\circledR}$ are not reliable sources of information about handmade masks.
\end{abstract}

Keywords: Centers for Disease Control and Prevention, Instructional Films and Videos, Masks, Social Media.

\section{ARAŞTIRMA}

\section{YOUTUBE@ PLATFORMUNDA SUNULAN EL YAPIMI MASKE VIDEOLARININ COVID-19 PANDEMISINDE GÜVENILIRLIĞI}

\section{$\ddot{O} z$}

Turan A, Kaya C. YouTube ${ }^{\circledR}$
Platformunda Sunulan El Yapımı Maske Videolarının COVID-19 Pandemisinde Güvenilirliği. Haliç Üniv Sağ Bil Der. $2021 ; 4(3)$ 225-233

Turan A, Kaya C. The Reliability of Handmade Mask Videos Presented on YouTube ${ }^{\circledR}$ Platform in COVID-19 Pandemic. Halic Uni J Health Sci. 2021;4(3) 225-233

Doi: 10.48124/husagbilder.966789

Geliş Tarihi: 08.07.2021 Kabul Tarihi: 15.08.2021

Bu çalışmada YouTube ${ }^{\circledR}$ üzerinden yayınlanan el yapımı maskeler ile ilgili eğitici videoların Hastalık Kontrol ve Önleme Merkezleri (CDC) ve Dünya Sağlık Örgütü (WHO) tarafından yayınlanan kriterlere uygun olup olmadığını belirlemeyi amaçladık. Bu çalışmada, 01 Ocak 2020 - 01 Nisan 2020 tarihleri arasında YouTube ${ }^{\circledR}$ 'da "DIY mask, handmade mask, fabric mask" anahtar kelimeleri ile yapılan arama sonucunda elde edilen 184 video incelenmiştir. Videolar WHO ve CDC tarafından önerilen kriterlere göre kategorilere ayrılmıştır. Toplam üye, görüntüleme, beğenme, beğenmeme, yapılan yorumlar, video kaynakları ve yükleme tarihi gibi izleyici parametreleri değerlendirildi. El yapımı maskelerle ilgili eğitici YouTube ${ }^{\circledR}$ videolarının $\% 66,8^{\prime} \mathrm{i}(\mathrm{n}=123)$ zanaat-kendin yap-eğitici sayfalar tarafından yüklendiği, \%57.1'inin ( $\mathrm{n}=105)$ dikiş yöntemini içerdiği, \%97,3'ünün ( $\mathrm{n}=179)$ uygun olmayan malzeme içerdiği saptandı. Videoların \%98,4'ünün (n=181) CDC direktiflerine uygun olmadığı, \%99,5'inde ( $\mathrm{n}=183)$ siviya dayanıklı olmayan malzeme kullandığı, \%78,3'ünde ( $\mathrm{n}=144)$ ağza temas edecek şekilde yapılan maskeler içerdiği ve \%95,7'sinde \% (n=176) yüz ve maske arasında boşluklar içeriyordu. YouTube ${ }^{\circledR}$ 'da yayınlanan el yapımı maskeler hakkındaki videoların güvenilir bilgi kaynağı olmadıkları saptandı.

Keywords: Hastalık Kontrol ve Önleme Merkezi, Eğitim Filmleri ve Videoları, Maskeler, Sosyal Medya. 


\section{Introduction}

The new Coronavirus disease 2019, "COVID-19" is a worldwide spread respiratory system disease and was first reported in Wuhan, in Hubei province in China in December 2019 $(1,2)$. Present data shows that respiratory droplets and contact are two main ways of transmission of the COVID-19 virus (3).

On 11 March 2020, World Health Organization (WHO) characterized COVID-19 as a pandemic (4). Besides, the WHO public health interventions working group proposes non-drug interventions as an important supplement because of the fact that sufficient drug supply cannot be provided promptly and may be inadequate for the whole population (5).

Pregnant women and their fetuses are considered as a high-risk population during infectious outbreaks. Besides, physiological changes in pregnancy could increase the occurrence of infections, especially when the cardiovascular and respiratory systems are affected (6). Furthermore, despite the postponement of gynecological surgeries except in emergency cases, it has been reported that gynecological cancer patients who are prone to be infected COVID-19, can be operated only after providing a suitable environment for patients and health-care providers (7).

In the guideline issued on 6 April 2020 by WHO, it pointed out that the need to wear a medical mask as one of the prevention procedures that can restrict the spread of respiratory viral infections, including COVID-19 (8). Accordingly, surgical masks were insufficient as a result of the increasing demand. People have had to use their masks repeatedly, and the number of hand-made mask manufacturers has increased (9).

On 9 April 2020, the Centers for Disease Control and Prevention (CDC) has published guidelines on making masks to prevent $\mathrm{CO}$ VID-19 (10,11). However, video sharing sites such as YouTube ${ }^{\circledR}$, which are visited by more than two billion users every month, have become the source of unreliable videos about handmade mask making, especially during the COVID-19 outbreak $(12,13)$.

In this study, we aimed to determine whether these instructive videos on handmade masks published on YouTube ${ }^{\circledR}$ are compatible with the criteria issued by CDC and WHO.

\section{Material and Method}

A video search was performed with the keywords "DIY mask, handmade mask, fabric mask", on YouTube ${ }^{\circledR}$ (https://www.YouTube ${ }^{\circledR}$. com) platform. Each video corresponding with the designated keyword criterion were assessed. The search consisted of videos uploaded from 01 January 2020 to 01 April 2020.

It was found that a total of 227 videos were uploaded within the specified date range. A total of 43 videos with descriptive content in languages apart from English and videos without mask making were left out. The study included 184 (81\%) eligible videos.

Validation from ethics committee was not necessary since this was an observational study using only data that is publicly available.

After the application of the exception criteria summarized above, every video was evaluated by the two researchers (AT, CK). The video sources such as surgeon/practitioner, hospital/free clinic, social media / TV channel, medical website, university and advertisement were registered. The tehonical elements such as the video upload date, the time since the video upload, views, likes, dislikes and comments, video duration, ratios such as like/view, like ratio (like $\times 100 /[$ like + dislike]), view ratio (number of views/days) and Video Power Index (VPI; like ratio $\times$ view ratio/100) (14) were noted.

The videos were reviewed in two categories. First, according to the criteria recommended by WHO: Fabric/texture layers numbers, breathability of the used material, water-repellent / hydrophobic properties, shape of the mask and fitting of the mask were recorded. Besides, the suggestions of WHO on mask use are as follows: A face shield or goggles should protect the eyes while at the same time the mouth and nose are preserved with a medical or surgical fluid-resistant mask which has a shaped style that does not fall on the mouth (e.g. duckbill or cup shape) $(8,15)$. The mask should be cautiously set up, making sure it covers the mouth and nose, and safely attached to minimize gaps between the face and the mask (8).

Second, the criteria by the CDC for DIY/ handmade masks were taken into consideration. It is advised by CDC to put on fabric face 
coverings in public places where other social distance measures (e.g. grocery stores and pharmacies) are difficult to keep, particularly in community-based transmission areas. Fabric face coverings, which are shaped from daily household items or using homemade materials (cotton fabric, t-shirt, square cotton fabric) at low cost can be an option to use as a supplementary voluntary public health measure $(10,11)$.

Duplicate videos and videos in which the number of likes, dislikes, or comments was disabled by the uploader were also omitted from the analysis.

Statistical analysis was applied using SPSS Version 20 (SPSS, Inc., Chicago, IL). To assess the agreement between the two independent reviewers, the Kappa coefficient was employed.

Averages, standard deviations and minimum - maximum for quantitative data and numbers and percentages for qualitative data were calculated.

\section{Results}

A significant agreement was observed between the reviewers considering video analysis (kappa coefficient 0.81 ). The results in Table 1 show that $66.8 \%$ (n:123) of the instructive YouTube ${ }^{\circledR}$ videos concerning handmade masks were uploaded by craft-DIY-tutorial pages, $57.1 \%$ (n:105) included the sewing method, $40.2 \%$ (n:74) used cotton fabric as material, 97.3\% (n:179) included unsuitable material usage as per CDC, 98.4\% (n:181) were not compatible with CDC directives, $49.5 \%$ (n:91) used 2 layers of fabric/tissue, $100 \%$ (n:184) used breathable fabric, 99.5\% (n:183) used non-fluid-resistant material, $78.3 \%$ (n:144) involved masks that collapse against the mouth and 95.7\% (n:176) involved gaps between the face and the mask (Table 1).

The results in Table 2 show that the time since the upload was $29.3207 \pm 12.57330$ days for the instructive YouTube ${ }^{\circledR}$ videos concerning handmade masks, with $368208.8424 \pm 1182219.11300$ views on average, $4114.1304 \pm 14131.85771$ likes on average, $219.0272 \pm 640.68111$ dislikes on average, $136.5 \pm 485.41967$ comments on average, mean duration of $379.4511 \pm 284.66012$ seconds, mean like/view ratio of $0.0555 \pm 0.15319$, mean like ratio of $91.9373 \pm 12.26032$, mean view ratio of $12463.1282 \pm 41605.20236$, mean Video Power Index of $10880.0308 \pm 37922.16285$ and $2.1522 \pm 2.37673$ layers of fabric/tissue on average (Table 2).

\section{Discussion}

In our study, we found that $40.2 \%$ (n:74) of the instructive YouTube ${ }^{\circledR}$ videos concerning handmade masks were made using cotton fabric as material.

There are no data in the literature on whether homemade masks and other materials are protective against Coronavirus. Van der Sande et al. (16) indicated that unapproved masks such as surgical and handmade can provide a significant decrease in aerosol exposure (16). Balazy et al. (17) found that to evaluate mask protection against biological particles of similar form and size, we can benefit from the use of non-biological particle stimulants (17). The lowest filtering performance of the masks for non-biological particles can also be implemented to virus-having particles. Davies et al. (18) found that the filtration efficiency for $B$ atrophaeus, which is a rod- shaped spore-forming bacterium, was $69.42 \%$ on average on $100 \%$ cotton t-shirt, $62.30 \%$ on scarf, $83.24 \%$ on tea towel, $61.28 \%$ on pillowcase, $65.62 \%$ on antimicrobial pillowcase, $94.35 \%$ on vacuum cleaner bag, $74.60 \%$ on cotton mix, $60 \%$ on linen and $58 \%$ on silk (18). As there is no reliable data on the permeability of coronavirus particles through handmade mask materials, the particle size of Bacillus atrophaeus, that ranges from $0.95-1.25 \mu \mathrm{m}(18,19)$, can be used as reference to compare the size of the coronavirus particles, which is $0.060-0.140 \mu \mathrm{m}$ $(20,21)$.

CDC published guidelines on the methods of making a mask, including Sewn Cloth Face Covering using cotton fabric, Quick Cut T-shirt Face Covering (no sew method) using a T-shirt, Bandana Face Covering (no sew method) using a bandana or any square cotton cloth $(10,11)$. In our study, we found that $32.6 \%$ (n:60) of the ins-

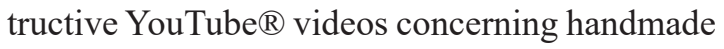
masks were not made with the materials proposed by the CDC, $97.3 \%$ included unsuitable 
material usage (quantity, length, capability and numbers of layers of fabric/tissue), $28.8 \%$ included unsuitable method (Gunk, Stapler, Knit) as per CDC. There is no evidence in literature that cotton fabric and similar materials used in the manufacture of handmade masks protect from COVID-19. WHO has made a number of recommendations to ensure that everyone is protected from COVID-19, including minimizing contact with people and frequent hand washing (8). For this reason, as it is an obvious wisdom that the use of handmade masks alone is not sufficient, the recommendations of WHO should be followed.

WHO advises that decision makers can proceed by recommending the use of non-medical masks. In such a situation, the following properties regarding non-medical masks should be considered: Number of fabric/texture layers, breathability of the material used, water-repellence / hydrophobic properties, mask form and fitting of the mask. WHO's suggestions on mask use are as follows: A face shield or goggles should protect the eyes while at the same time the mouth and nose are preserved with a medical or surgical fluid-resistant mask which has a shaped style that does not fall on the mouth (e.g. duckbill or cup shape) $(8,15)$. In our study, we found that $100 \%$ used breathable fabric, $99.5 \%$ used non-fluid-resistant material, $78.3 \%$ involved masks that collapse against the mouth and $95.7 \%$ involved gaps between the face and the mask. The reason that the breathability of the materials used in making the mask is $100 \%$, even though the material used is not breathable (e.g. skin, plastic), is caused by opening holes on them to breathe. None of the videos had duckbill or cup shapes, which WHO suggested. But $21.3 \%$ made the mask shape similar to duckbill. Despite the use of insufficient material, $4.3 \%$ of the videos used metal that could take shape to prevent any gaps with the face / nose.

Up to now, two researchers in the field of gynecology have published the reliability of YouTube ${ }^{\circledR}$ videos. Kaya et al. (22) reported that YouTube ${ }^{\circledR}$ is not a reliable platform regarding endometrioma cystectomy procedure (22). Besides, Orhan et al. (23) reported that YouTube ${ }^{\circledR}$ has a negative impact on the mesh-related discussions (23). In general, previous studies have also identified that the data obtained from YouTube ${ }^{\circledR}$ videos on health-related issues are weak, insufficient, and unconfirmed due to no scientific approval or data standardization (2426).

Furthermore, the credibility of the results was inconsistent, depending on the scope of interest and data source (27-29). In our study, we discovered that craft-DIY-tutorial pages uploaded $66.8 \%$ of the informative YouTube ${ }^{\circledR}$ videos concerning handmade masks. We suggest that the practices performed to protect and maintain health (such as mask-making) should be followed from the guidelines published by CDC and WHO, which are reliable health authorities.

Most of the population is reported to tend to view misleading videos more frequently than dependable videos. Lee et al. informed that videos regarded as very useful received much less views and likes than misleading videos (30). On the contrary, Sahin et al. (24) assessed videos of premature retinopathy, and beneficial videos appeared to have more views and likes than misleading videos [24]. In our study, we discovered instructive YouTube ${ }^{\circledR}$ videos concerning handmade masks, with $368208.8424 \pm 1182219.11300$ views on average, $4114.1304 \pm 14131.85771$ likes on average, $219.0272 \pm 640.68111$ dislikes on average, mean like ratio of $91.9373 \pm 12.26032$, mean Video Power Index of 10880.0308 \pm 37922.16285 . These results are in the same line with the previous research results.

There are few limitations in our study. First, to interpret the videos, subjective score criteria were exercised since there is no approved tool for evaluating video data yet. Second, these results show the information quality at certain point, and the results may change over time as videos are uploaded or removed. As the third; content was searched only from YouTube ${ }^{\circledR}$. The results on other websites may differ. Therefore, we cannot generalize our results for all web platforms describing handmade masks.

\section{Conclusions}

The videos published on YouTube ${ }^{\circledR}$ videos are not reliable sources of information about 
handmade masks. For this reason, we suggest that the applications (such as mask making) performed in order to protect and maintain health should be carried out in accordance with the guidelines of reliable health authorities.

\section{Acknowledgment}

None.

\section{Author contributions}

Concept- A. Turan, C. Kaya; Design- A. Turan, C. Kaya; Supervision- A. Turan, C. Kaya; Resources- A. Turan, C. Kaya; Materials- A. Turan, C. Kaya; Data Collection and/or Processing- A. Turan, C. Kaya; Analysis and/ or Interpretation- A. Turan, C. Kaya; Literature Search- A. Turan, C. Kaya; Writing ManuscriptA. Turan; Critical Review- A. Turan

\section{Funding}

This research did not receive any specific grant from funding agencies in the public, commercial, or not-for-profit sectors.

\section{Conflict of interest}

None.

\section{References}

1. Wang C, Horby PW, Hayden FG, Gao GF. A novel coronavirus outbreak of global health concern. The Lancet. 2020;395:470-473. doi: 10. 1016/S0140-6736(20)30185-9.

2. Singhal T. A review of coronavirus disease-2019 (COVID-19). The Indian Journal of Pediatrics. 2020;87:281-286. doi: 10.1007/s12098-02003263-6.

3. World Health Organization (WHO). Water, Sanitation, Hygiene and Waste Management for COVID-19 [WHO website]. https://www.who. int/publicationsdetail/water-sanitation-hygiene-and-wastemanagement-for-covid-19. Accessed April 11, 2020.

4. World Health Organization (WHO). Coronavirus Disease (COVID-19) Outbreak [WHO website]. https://www.who.int/westernpacific/emergencies/covid-19. Accessed April 11, 2020.
5. World Health Organization (WHO). WHO Consultation on Priority Public Health Interventions Before and During an Influenza Pandemic [WHO website]. 2004. https://apps.who.int/iris/bitstream/handle/10665/232425/WER7911_107108.PDF? sequence $=1 \&$ isAllowed $=y$. Accessed April 11, 2020.

6. Yassa M, Birol P, Mutlu AM, Tekin AB, Sandal K, Tug N. Lung Ultrasound Can Influence the Clinical Treatment of Pregnant Women with COVID-19. J Ultrasound Med. 2020;9999:1-13. doi: 10.1002/jum.15367.

7. Dursun P, Dervisoglu H, Daggez M, et al. Performing gynecologic cancer surgery during the COVID-19 pandemic in Turkey: A multicenter retrospective observational study. Int J Gynecol Obstet. 2020 [preprint]. doi: 10.1002/ijgo.13296.

8. World Health Organization (WHO). Advice on the Use of Masks in the Context of COVID-19 [WHO website]. 2020. https://www. who.int/publications-detail/advice-on-the-use-of-masks-in-thecommunity-during-home-care-and-in-healthcare-settings-in-the-context-of-the-novelcoronavirus-(2019-ncov)-outbreak. Accessed April 11, 2020.

9. Wang M, Zhou M, Ji G, et al. Mask crisis during the COVID-19 outbreak. European Review for Medical and Pharmacological Sciences. 2020;24:3397-3399. doi: 10.26355/ eurrev_202003_20707.

10. Centers for Disease Control and Prevention (CDC). Use of Cloth Face Coverings to Help Slow the Spread of COVID-19 [CDC website]. 2020. https://www.cdc.gov/coronavirus/2019-ncov/prevent-getting-sick/diy-cloth-face-coverings.html. Accessed April 11, 2020.

11. Centers for Disease Control and Prevention (CDC). Recommendation Regarding the Use of Cloth Face Coverings, Especially in Areas of Significant Community-Based Transmission [CDC website]. 2020. https://www.cdc.gov/coronavirus/2019-ncov/prevent-getting-sick/cloth-face-cover.html. Accessed April 11, 2020.

12. Perrin A, Duggan M. Americans' Internet Access: 2000-2015, Vol. 2019. Pew Internet and American Life Project. Washington, DC: Pew Research Center [website]. 2015. https://www. pewresearch.org/internet/2015/06/26/americans-internet-access-2000-2015/. Accessed April 11, 2020. 
13. YouTube $\AA$. Statistics for YouTube $\AA$ [YouTube $\AA$ website]. https://www.YouTube ${ }^{\circledR}$.com/about/ press/. Accessed April 11, 2020.

14. Erdem MN, Karaca S. Evaluating the accuracy and quality of the information in kyphosis videos shared on YouTube ${ }^{\circledR}$.Spine (Phila Pa 1976). 2018;43:e1334-e1339. doi: 10.1097/ BRS.0000000000002691.

15. World Health Organization (WHO). Personal protective equipment for use in a filovirus disease outbreak: rapid advice guideline [WHO website]. 2016.https://apps.who.int/iris/ handle/10665/251426. Accessed April 11, 2020.

16. Van Der Sande M, Teunis P, Sabel R. Professional and homemade face masks reduce exposure to respiratory infections among the general population. Plos One. 2008;3:e2618. doi: 10.1371/ journal.pone.0002618.

17. Balazy A, Toivola M, Adhikari A, Sivasubramani SK., Reponen T, Grinshpun SA. Do N95 respirators provide $95 \%$ protection level against airborne viruses, and how adequate are surgical masks?. American Journal of Infection Control. 2006;34:51-57. doi: 10.1016/j.ajic.2005.08.018.

18. Davies A, Thompson KA, Giri K, Kafatos G, Walker J, Bennett A. Testing the efficacy of homemade masks: would they protect in an influenza pandemic?. Disaster Medicine and Public Health Preparednesss. 2013;7:413-418. doi: 10.1017/dmp.2013.43.

19. Cox C. The Aerobiological Pathway of Microorganisms. Chichester, UK: John Wiley \& Sons; 1987. doi: 10.1002/abio.370080416.

20. Chen N, Zhou M, Dong X, et al. Epidemiological and clinical characteristics of 99 cases of 2019 novel coronavirus pneumonia in Wuhan, China: a descriptive study. The Lancet. 2020;395:507513. doi:10.1016/S0140-6736(20)30211-7.

21. Zhu N, Zhang D, Wang W, et al. A novel coronavirus from patients with pneumonia in China, 2019. New England Journal of Medicine. 2020;382:727-733. doi: 10.1056/NEJMoa2001017.
22. Kaya C, Usta T, Baghaki HS, Oral E. Relation between educational reliability and viewer in-

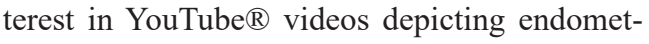
rioma cystectomy surgical techniques. Journal of Gynecology Obstetrics and Human Reproduction. 2020 [preprint]. doi:10.1016/j.jogoh.2020.101808.

23. Orhan A, Gokturk GG, Ozerkan K, Kasapoglu I, Aslan K, Uncu G. Mesh complications on YouTube. European Journal of Obstetrics \& Gynecology and Reproductive Biology. 2020;252:144149. doi:10.1016/j.ejogrb.2020.06.040.

24. Şahin A, Şahin M, Türkcü FM. YouTube ${ }^{\circledR}$ as a source of information in retinopathy of prematurity. Ir J Med Sci. 2019;188:613-617. doi: 10.1007/s11845-018-1902-2.

25. Brooks FM, Lawrence H, Jones A, McCarthy MJ. YouTube ${ }^{\circledR}$ TM as a source of patient information for lumbar discectomy. Ann R Coll Surg Engl. 2014;96:144-146. doi: 10.1308/00358841 4X13814021676396.

26. Madathil KC, Rivera Rodriguez AJ, Greenstein JS, Gramopadhye AK. Healthcare information on YouTube ${ }^{\circledR}$ : A systematic review. Health Informatics J. 2015;21:173-194. doi: $10.1177 / 1460458213512220$.

27. Ocak U. Evaluation of the Content, Quality, Reliability and Accuracy of YouTube ${ }^{\circledR}$ Videos Regarding Endotracheal Intubation Techniques. Niger. J Clin Pract. 2018;21:1651-1655. doi: 10.4103/njcp.njcp_207_18.

28. Bezner SK, Hodgman EI, Diesen DL, et al. Pediatric surgery on YouTube ${ }^{\circledR}$ TM: Is the truth out there?. J Pediatr Surg. 2014;49:586-589. doi: 10.1016/j.jpedsurg.2013.08.004.

29. Shires CB, Wilson CD, Sebelik M. Thyroid surgery YouTube ${ }^{\circledR}$ videos: estimating quality by surgeon characteristics and view rate. Gland Surg. 2019;8:207-211. doi: 10.21037/ gs.2018.10.01.

30. Lee JS, Seo HS, Hong TH. YouTube ${ }^{\circledR}$ as a source of patient information on gallstone disease. World Journal of Gastroenterology: WJG. 2014;20:4066-4070. doi: 10.3748/wjg.v20. i14.4066. 
Table 1. Results of the analysis of the 184 YouTube ${ }^{\circledR}$ videos.

\begin{tabular}{|c|c|c|}
\hline Variables $(\mathrm{N}=\mathbf{1 8 4})$ & $\mathrm{n}$ & $\%$ \\
\hline \multicolumn{3}{|l|}{ Upload Source } \\
\hline Civilian & 37 & 20.1 \\
\hline Commercial Website & 1 & .5 \\
\hline Craft-DIY-Tutorial Page & 123 & 66.8 \\
\hline Drawing Page & 2 & 1.1 \\
\hline Florist Page & 1 & .5 \\
\hline Food Page & 5 & 2.7 \\
\hline Game Page & 2 & 1.1 \\
\hline Health and Beauty Page & 4 & 2.2 \\
\hline Leather Page & 1 & .5 \\
\hline News Page & 1 & .5 \\
\hline Religious Page & 1 & .5 \\
\hline Sewing Page & 6 & 3.3 \\
\hline \multicolumn{3}{|l|}{ Sew or no sew method } \\
\hline Gunk & 27 & 14.7 \\
\hline Gunk+Stapler & 1 & .5 \\
\hline Knit & 6 & 3.3 \\
\hline No Sew & 26 & 14.1 \\
\hline Sew & 105 & 57.1 \\
\hline Stapler & 19 & 10.3 \\
\hline \multicolumn{3}{|c|}{ Materials (Cotton Fabric, T-shirt, Bandana, Square Cotton Cloth) } \\
\hline Acrylic Yarn & 6 & 3.3 \\
\hline Bandana & 2 & 1.1 \\
\hline Bed Sheet & 1 & .5 \\
\hline Bra & 1 & .5 \\
\hline Cloth Bag & 46 & 25.0 \\
\hline Cotton Fabric & 74 & 40.2 \\
\hline Cotton Fabric+PaperTowel+Removable Pad & 1 & .5 \\
\hline Cotton Fabric+Sponge & 1 & .5 \\
\hline Handkerchief & 13 & 7.1 \\
\hline Leather & 1 & .5 \\
\hline Leggings & 2 & 1.1 \\
\hline Men’s Underwear & 1 & .5 \\
\hline Napkin & 1 & .5 \\
\hline Paper Towel & 19 & 10.3 \\
\hline Paper Towel+Removable Pad & 1 & .5 \\
\hline Plastic Bottle & 1 & .5 \\
\hline Removable Pad & 2 & 1.1 \\
\hline Silver Fiber & 1 & .5 \\
\hline Socks & 1 & .5 \\
\hline
\end{tabular}




\begin{tabular}{|c|c|c|}
\hline Variables $(\mathrm{N}=184)$ & $\mathbf{n}$ & $\%$ \\
\hline T-shirt & 2 & 1.1 \\
\hline Vacuum Bag & 1 & .5 \\
\hline Vegetable Carry Bag & 1 & .5 \\
\hline Wet Wipes & 5 & 2.7 \\
\hline \multicolumn{3}{|l|}{ Material Suitability According to CDC } \\
\hline Suitable & 5 & 2.7 \\
\hline Unsuitable & 179 & 97.3 \\
\hline \multicolumn{3}{|l|}{ Compliance with CDC Directives } \\
\hline Yes & 3 & 1.6 \\
\hline No & 181 & 98.4 \\
\hline \multicolumn{3}{|l|}{ Numbers of layers of fabric/tissue } \\
\hline 1 & 74 & 40.2 \\
\hline 2 & 91 & 49.5 \\
\hline 3 & 5 & 2.7 \\
\hline 4 & 5 & 2.7 \\
\hline 6 & 1 & .5 \\
\hline 9 & 2 & 1.1 \\
\hline 12 & 4 & 2.2 \\
\hline 15 & 1 & .5 \\
\hline 18 & 1 & .5 \\
\hline \multicolumn{3}{|l|}{ Breathability of the material used } \\
\hline Breathable & 184 & 100.0 \\
\hline Non-breathable & 0 & 0 \\
\hline \multicolumn{3}{|l|}{ Water repellence/hydrophobic qualities } \\
\hline Fluid-resistant & 1 & .5 \\
\hline Not fluid-resistant & 183 & 99.5 \\
\hline \multicolumn{3}{|l|}{ Shape of the mask } \\
\hline Does not collapse against the mouth & 40 & 21.7 \\
\hline Collapses against the mouth & 144 & 78.3 \\
\hline \multicolumn{3}{|c|}{ Fit of the mask (gaps vs. no gaps between the face and the mask } \\
\hline Gaps between the face and the mask & 176 & 95.7 \\
\hline No gaps between the face and the mask & 8 & 4.3 \\
\hline
\end{tabular}

$\mathrm{n}$ : sample size 
Table 2. Results of the analysis of the 184 YouTube ${ }^{\circledR}$ videos.

\begin{tabular}{llll}
\hline Variables (N=184) & $\mathbf{X}$ & SD & Min-Max \\
\hline Time since the video upload (days) & 29.3207 & 12,57330 & $14-82$ \\
Views & 368208,8424 & 1182219,11300 & $1-11295183$ \\
Likes & 4114,1304 & 14131,85771 & $0-108000$ \\
Dislikes & 219,0272 & 640,68111 & $0-5600$ \\
Comments & 136,5 & 485,41967 & $0-4800$ \\
Duration of the Video (seconds) & 379,4511 & 284,66012 & $71-1784$ \\
Ratios like/view &, 0555 &, 15319 & $0-1.67$ \\
Like ratio & 91,9373 & 12,26032 & $0-100$ \\
View ratio & 12463,1282 & 41605,20236 & $0,04-322719,51$ \\
Video Power Index & 10880,0308 & 37922,16285 & $0-306810,81$ \\
\hline
\end{tabular}

$\mathrm{X}$ : Mean, SD: Standart Deviation 
